\title{
Application of Principal Component Factor Analysis in Quantifying Size and Morphological Indices of Domestic Rabbits
}

\author{
Aplicación del Análisis Factorial de Componentes Principales en la Cuantificación \\ de los Índices de Tamaño y Morfología de los Conejos Domésticos
}

A. Yakubu \& J. A. Ayoade

\begin{abstract}
YAKUBU, A. \& AYOADE, J. A. Application of principal component factor analysis in quantifying size and morphological indices of domestic rabbits. Int. J. Morphol., 27(4):1013-1017, 2009.

SUMMARY: Body weight and four morphostructural traits namely body length, heart girth, thigh circumference and ear length of 103 New Zealand White x Chinchilla crossbred rabbits were measured. The investigation aimed at describing objectively the interdependence among conformation traits and to predict body weight from their independent factor scores using principal component analysis. Phenotypic correlations between body weight and body dimensions were highly significant $(\mathrm{r}=0.61-0.91 ; \mathrm{P}<0.01)$. Pairwise correlations of the body shape characters ranged from moderate to high values. From the factor analysis with varimax rotation of the intercorrelated traits, two principal components which accounted for $90.27 \%$ of the total variance were extracted. The first principal component, PC1 termed general size, had its loadings for body length, heart girth and thigh circumference and explained $74.98 \%$ of the variance. Ear length primarily determined the second principal component, PC 2 which contributed to $15.29 \%$ of the generalized variance. Orthogonal body shape characters derived from the factor analysis accounted for $81.7 \%$ of the variation in body weight of rabbits. The PC-based prediction model is preferable to linear measure-based models for selecting animals for optimal balance since it combines both size and shape components into a composite index for prediction.
\end{abstract}

KEY WORDS: Body size; Growth; Rabbits.

\section{INTRODUCTION}

Domestic rabbits grow rapidly and their growth rate is comparable to that of chickens. Body size and conformation (shape) are important traits in meat animals. Whereas the former has been largely estimated quantitatively by scale weight, the latter has generally been described by visual appraisal, giving rise to subjective scores. Body measurements have been used in rabbits to contrast variation in size and shape (Yakubu et al., 2004; Oliveira et al., 2004; Wu et al., 2008). However, the biological relationship existing among the linear body traits may be different if these body dimensions are treated as bivariates rather than multivariates. Since body measurements are intercorrelated both phenotypically and genetically (Lukefahr \& Ozimba, 1991; El-Mahdy, 1998; Akanno \& Ibe, 2005), the analysis of these traits should address interdependence among the explanatory variables (predictors).

Principal component analysis could be used with success when morphological characteristics are interdependent. This is to find the loadings or factors that explain the highest variation in the data set over the dependent variable. The resulting principal components or loadings may decrease the dimension of the explanatory variables and break the possible dependence among explanatory variables, hence multicollinearity. Where multicollinearity exists among the predictors, linear regression assumptions (linearity, independence, homoscedasticity and normality) could not be validated.

Many workers have used independent factor scores derived from multivariate technique of factor analysis as predictors of total carcass, muscle, fat and bone and other functional traits (Shahin, 1997, 1999; Karacaören \& Kadarmideen, 2008) and as a selection criterion for the improvement of size (Pinto et al., 2006).

In the sub-humid tropics, the interrelationships among body measurements and body weight of rabbits using a 
multivariate approach have not been widely exploited. Therefore, this study was undertaken to provide an objective description of body shape using principal components, and to predict body weight from body measurements of rabbits using orthogonal conformation traits derived from the principal component factor analysis.

\section{MATERIAL AND METHOD}

Study location. The study was conducted in the rabbitry of Small Animal Section of the National Veterinary Research Institute (NVRI) Vom, Plateau State. The area is $1.280 \mathrm{~m}$ above sea level and lies on longitude $8^{\circ} 45^{\prime}$ East and latitude $9^{\circ} 43^{\prime}$ North. The mean annual rainfall ranges between 1.250 to $1.650 \mathrm{~mm}$, and this extends from April to October. The average air temperature ranges from 19.5 to $23.5^{\circ} \mathrm{C}$.

Experimental animals and their management. One hundred and three New Zealand White x Chinchilla crossbred rabbits over 60 weeks old were sampled. The rabbits were housed in groups in metal cages located in a well-ventilated building. All cages were fitted with aluminium feeders and drinkers. The animals bore identification numbers on their ears. They were fed ad libitum, a concentrate diet containing $16 \% \mathrm{CP}$ supplemented with green forages. Fresh clean water was also freely available. All animals were treated and medicated similarly throughout the study period under the same managerial and climatic conditions.

Traits measured. Body weight (BW) and four external body measurements were taken on each animal. The parts measured were body length (BL), diagonal distance from the point of the shoulder to the pinbone (Tuber ischi), heart girth (HG), measured as circumference of the thoracic cavity just behind the fore limbs; thigh circumference (TC), circumference at the knee-cap (patella) and ear length (EL), distance from the base of the ear to its tip. Body weight was taken using a 10-kg scale while the circumference and length measurements were taken early in the morning before the animals were fed. All measurements and weightings were taken by the same person to avoid individual variations.

Statistical Analysis. Mean, standard deviation and coefficient of variation of each measurement were computed. The correlation coefficients of body weight and the linear body measurements were also determined. From the correlation matrix, data for the principal component factor analysis were generated. According to Everitt et al. (2001), principal component analysis is a method for transforming the variables in a multivariate data set $\mathrm{x}_{1}, \mathrm{x}_{2},---, \mathrm{x}_{\mathrm{p}}$, into new variables, $\mathrm{y}_{1}, \mathrm{y}_{2},---, \mathrm{y}_{\mathrm{p}}$ which are uncorrelated with each other and account for decreasing proportions of the total variance of the original variables defined as:

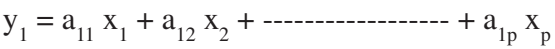

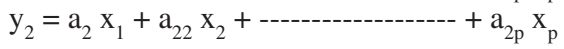

$$
\begin{aligned}
& y_{p}=a_{p 1} x_{1}+a_{p 2} x_{2}+-----------+a_{p p} x_{p}
\end{aligned}
$$

with the coefficients being chosen so that $\mathrm{y}_{1}, \mathrm{y}_{2},------, \mathrm{y}_{\mathrm{p}}$ account for decreasing proportions of the total variance of the original variables, $x_{1}, x_{2},-----, x_{p}$.

During the evaluation, factors were rotated with varimax rotation of Kaiser. The aim of the Varimax rotation is to maximize the sum of variances of $\mathrm{a}_{\mathrm{ij}}{ }^{2}$ quadratic weight. The stepwise variable selection multiple regression procedure was used to obtain models for predicting body weight from body measurements (a) and from established principal components (b).

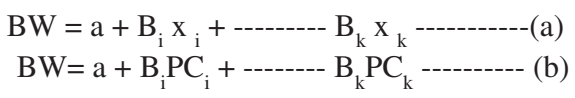

where; $\mathrm{BW}$ is the body weight, a is the regression intercept, $B_{1}$ is the $i$-th partial regression coefficient of the $i$ th linear body measurement, $\mathrm{X}_{\mathrm{i}}$ or the $\mathrm{i}$-th principal component.

The factor programme of SPSS (2001) statistical package was used for the analysis.

\section{RESULTS AND DISCUSSION}

Bodyweight and morphostructural traits. Means, standard deviations and coefficients of variation of bodyweight and conformation traits of rabbits are presented in Table I. Bodyweight, thigh circumference, heart girth and body length were more variable. This could be attributed to some degree of environmental effects and the condition of each animal. Ear length showed less variability perhaps as a result of breed specificity and lesser influence of the environment on its manifestation.

Phenotypic Correlation. Pearson's coefficient of correlation matrix for body weight and body measurements is shown in Table II. Moderate to high estimates were attained for the variables. All the body measurements were highly associated with bodyweight. However, the highest correlation coefficients were recorded with heart girth and thoracic circumference (0.91 and 0.84). Similar findings have been reported (Shahin \& Hassan, 2000; Abdullah et $a l ., 2003)$. The thigh is the area where there is the highest 
Table I. Descriptive statistics of bodyweight $(\mathrm{kg})$ and linear body measurements $(\mathrm{cm})$ of New Zealand White x Chinchilla crossbred rabbits.

\begin{tabular}{lcccc}
\hline Traits & N & S.D. & Mean & $\begin{array}{c}\text { Coefficient of } \\
\text { variation }\end{array}$ \\
\hline Body weight & 103 & 0.56 & 2.92 & 19.18 \\
Body length & 103 & 3.27 & 26.31 & 12.43 \\
Heart girth & 103 & 4.06 & 30.03 & 13.52 \\
Thigh circumference & 103 & 2.09 & 11.14 & 18.76 \\
Ear length & 103 & 0.93 & 12.19 & 7.63 \\
\hline
\end{tabular}

muscle deposition in the rabbit body (Oliveira et al.) hence, its high relationship with bodyweight while the heart girth reflects gut fill. This implies that selection for any of these traits will lead to improvement in the other. More importantly, any of these body dimensions could serve as a predictor of body weight.

Table II. Coefficients of correlation among bodyweight and linear body measurements of rabbits

\begin{tabular}{llllll}
\hline & BW & BL & HG & TC & EL \\
\hline BW & - & 0.74 & 0.91 & 0.84 & 0.61 \\
BL & - & - & 0.75 & 0.77 & 0.42 \\
HG & - & - & - & 0.82 & 0.63 \\
TC & - & - & - & - & 0.56 \\
\hline
\end{tabular}

Table III. Principal component weights for the body dimensions of rabbits.

\begin{tabular}{lllc} 
Traits & PC1 & PC2 & Communality \\
\hline Body length & 0.936 & 0.488 & 0.884 \\
Heart girth & 0.796 & 0.370 & 0.871 \\
Thigh circumference & 0.857 & 0.140 & 0.872 \\
Ear length & 0.260 & 0.955 & 0.979 \\
\% of total variance & 74.98 & 15.29 & \\
Description & General size & Ear length & \\
\hline
\end{tabular}

Principal Component Matrix. After varimax rotation, principal component weights derived from the correlation matrix of the four linear body measurements are presented in Table III. These coefficients show the relative contribution of each trait to a particular principal component (factor). Two principal components (PC1 and PC2) were extracted which contributed to $90.27 \%$ of the total variance. The percentage of total variance is used as an index to determine how well the total factor solutions account for what the variables (in this case, the four body measurements) together represent. PC1 was characterized by high positive loadings (factor-variate correlations) on all body measurements except ear length. It explains $74.98 \%$ of the total variation and represents 'general size'. The body parts (body length, heart girth and thigh circumference) associated with PC1 are by themselves rather good estimator of general size. The present findings are in consonance with the observation of Shahin \& Hassan in New Zealand White rabbits that the first factor (general size) explained the highest percentage of the total variance. Similarly (Shahin et al., 1993) reported in Egyptian buffalo that the first factor was characterized by high positive loadings on all body shape characters; the variables associated with body length had the highest loading, followed by heart girth and abdominal girth. It also

Table IV. Stepwise multiple regression of body weight on the original body measurements and on their principal components. R2 $=$ Coefficient of determination; $\mathrm{PC} 1$ and $\mathrm{PC} 2=1^{\text {st }}$ and $2^{\text {nd }}$ principal component respectively.

\begin{tabular}{|c|c|c|c|}
\hline Variables & Models & $\mathbf{R}^{2}$ & S. E \\
\hline \multicolumn{4}{|c|}{$\begin{array}{l}\text { I. Original body measurements as independent } \\
\text { variables }\end{array}$} \\
\hline Heart girth & $\mathrm{BW}=0.500+0.081 \mathrm{HG}$ & 0.829 & 0.15 \\
\hline Heart girth and thigh circumference & $\mathrm{BW}=0.577+0.060 \mathrm{HG}+0.048 \mathrm{TC}$ & 0.854 & 0.14 \\
\hline Heart girth and body length & $\mathrm{BW}=0.377+0.072 \mathrm{HG}+0.015 \mathrm{BL}$ & 0.837 & 0.15 \\
\hline Thigh circumference and body length & $\mathrm{BW}=0.988+0.113 \mathrm{TC}+0.026 \mathrm{BL}$ & 0.725 & 0.19 \\
\hline \multicolumn{4}{|c|}{ II. Orthogonal traits as independent variables } \\
\hline PC1 & $\mathrm{BW}=2.923+0.281 \mathrm{PC} 1$ & 0.612 & 0.23 \\
\hline $\mathrm{PC} 1$ and $\mathrm{PC} 2$ & $\mathrm{BW}=2.923+0.281 \mathrm{PC} 1+0.163 \mathrm{PC} 2$ & 0.817 & 0.16 \\
\hline
\end{tabular}


corroborates the submission of Salako (2006) that the first principal component comprising seven measurements (foreleg length, tail length, face length, rump height, withers height, body length and heart girth) explained $67.7 \%$ of the generalized variance and can be considered as a generalized size factor. PC2 which was mutually orthogonal to $\mathrm{PC} 1$, presented patterns of variation independent of general size (multicollinearity already avoided). It was primarily related to ear length, accounting for $15.29 \%$ of the total variance, this component could be called an ear length factor. The large communalities (0.871-0.979) observed indicate that a large number of variance has been accounted for by the factor solution. For body length, it means that about $89 \%$ of its variance has been captured by the two principal components together. PC1 and PC2 could be interesting for the purpose of evaluation and comparison of animals. Since the correlation between principal components is zero, the selection of animals for any principal component will not cause correlated response in terms of other principal components (Pinto et al.).

\section{Prediction of body weight of rabbits from} interdependent body measurements and their independent principal components.

The interdependent conformation traits and their independent factor scores were used to predict body weight of rabbits (Table IV). Heart girth alone explained about $83 \%$ of the variation in bodyweight. When thigh circumference was added to the model, the proportion of explained variance increased to $85 \%$. The combinations of heart girth and body length, and thigh circumference and body length accounted for about $84 \%$ and $73 \%$ of the variability in bodyweight, respectively. This result indicates that body weight can be predicted with a fair degree of accuracy from body dimensions. Similar findings have been reported by other workers (Yakubu et al., 2007; Wu et al.; Teguia et al., 2008). However, the use of body measurements to predict body weight/growth should be treated with caution due to multicollinearity, which has been shown to be associated with unstable regression estimates (Ibe, 1989), thereby, leading to unreliable predictions. This justifies the use of indices of the body measurements, referred to as principal components for prediction, since they are orthogonal to each other. In this wise, $\mathrm{PC} 1$ contributed to about $61 \%$ of the total variation in body weight when used as a sole predictor. When both PC1 and PC2 were combined, the coefficient of determination (R2) progressively improved to about $82 \%$. All the regression models were significant at $\mathrm{P}<0.01$.

\section{CONCLUSION}

The present principal component analysis provided a means for objective description of the interdependence in the original four body measurements (body length, heart girth, thigh circumference and ear length) of rabbits. The use of orthogonal body shape characters (PC1 and PC2) derived from the principal component factor solution could be more reliable in predicting body weight compared to the use of the original intercorrelated body measurements. This is because multicollinearity of interdependent explanatory variables could lead to erroneous inferences when original body measurements are used as predictors.

YAKUBU, A. \& AYOADE, J. A. Aplicación del análisis factorial de componentes principales en la cuantificación de los índices de tamaño y morfología de los conejos domésticos. Int. J. Morphol., 27(4):1013-1017, 2009.

RESUMEN: Los objetivos de la investigación fueron determinar el peso corporal y cuatro rasgos morfoestructurales denominados longitud corporal, circunferencia cardiaca, circunferencia del muslo y longitud de la oreja de 103 mestizos de conejos blancos de Nueva Zelanda x Chinchilla. Además, describir la interdependencia entre los rasgos de conformación y predecir el peso corporal desde los resultados de sus factores independientes mediante el análisis de los componentes principales. Correlaciones fenotípicas entre el peso corporal y las dimensiones corporales fueron altamente significativas $(\mathrm{r}=0,61-0,91 ; \mathrm{P}<0,01)$. Correlaciones pareadas de los caracteres de la forma del cuerpo variaron de valores moderados a altos. Fueron extraídos dos componentes principales, desde el análisis factorial con rotación Varimax de los rasgos intercorrelacionados, que representan el 90,27\% de la varianza total. El primer componente principal, denominado tamaño general PC1, tiene su carga para longitud corporal, circunferencia cardiaca y circunferencia del muslo y explican el 74,98\% de la varianza. La longitud de la oreja determina principalmente el segundo componente principal, PC2 que contribuyó al $15,29 \%$ de la varianza generalizada. Los caracteres ortogonales de la forma del cuerpo derivados del análisis factorial representaron el $81,7 \%$ de la variación en el peso corporal de los conejos. Para la selección de animales para un óptimo balance, el PC basado en modelos de predicción es preferible a los basados en modelos de medición lineal ya que combina el tamaño y componentes de la forma en un índice compuesto para predicción.

PALABRAS ClAVE: Tamaño corporal; Crecimiento; Conejos. 


\section{REFERENCES}

Abdullah, A. R.; Sokunbi, O. A.; Omisola, O. O. \& Adewumi M. K. Interrelationship between body weight and body linear measurements in domestic rabbit (Oryctolagus cuniculus). Proceedings of the $28^{\text {th }}$ Annual Conference of Nigerian Society for Animal Production at Institute of Agricultural Research and Training Obafemi Awolowo University, Ibadam Nigeria, 122-4, 2003.

Akanno, E. C. \& Ibe, S. N. Estimates of genetic parameters for growth traits of domestic rabbits in the humid tropics. Livestock Research for Rural Development, http:// www.cipav.oorg.co//rrd17/7/akau- 17086.htm, 2005.

El-Mahdy, M. R. M. Evaluation of live body and carcass of broiler rabbits at marketing. Egypt. J. Rabbit Sci., 8:6981, 1998.

Everitt, B. S.; Landau, S. \& Leese, M. Cluster Analysis. $4^{\text {th }}$ edition. London, Arnold Publisher, 2001.

Ibe, S. N. Measures of size and conformation in commercial broilers. J. Anim. Breed. Genet., 106:461-9, 1989.

Karacaören, B. \& Kadarmideen, H. N. Principal component and clustering analysis of functional traits in Swiss dairy cattle. Turk. J. Vet. Anim. Sci., 32(3):163-71, 2008.

Lukefahr, S. D. \& Ozimba, C. E. Prediction of carcass merit from live body measurements in rabbit of four breedtypes. Livest. Prod. Sci., 29(4):323-34, 1991.

Oliveira, M. C.; Moura, C. D.; Arantes, U. M.; Faria, E. B.; Lui, J. F. \& Caires, D. R. Body measurements and its coefficient of correlation with the performance index of sexed rabbits slaughtered at different ages. http:// w w w.d c a m. upv.es / 8 w r c/d ocs / Genetics \% 20and\%20Biotechnology/shortpapers/110-11, 2004

Pinto, L. F. B.; Packer, I. U.; De Melo, C. M. R.; Ledur, M. C. \& Coutinho, L. L. Principal components analysis applied to performance and carcass traits in the chicken. Anim. Res., 55:419-25, 2006.

Salako, A. E. Principal component factor analysis of the morphostructure of immature $\mathrm{Uda}$ sheep. Int. J. Morphol., 24(4):571-4, 2006.

Shahin, K. A.; Soliman, A. M. \& Moukhtar, A. E. Sources of shared variability for the egyptian buffalo body shape (conformation). Livest. Prod. Sci., 36(4):323-34, 1993.
Shahin, K. A. Sources of shared variability in muscle and bone weight distribution and estimation of carcass meatiness and bone utilizing orthogonal carcass traits derived from factor analysis in Japanese quail. Ann. Zootech., 46:175-83, 1997.

Shahin K. A. Sources of shared variability in muscle and fat weight distribution in Pekin ducklings. Ann. Zootech., 48:59-66, 1999.

Shahin K. A. \& Hassan, N. S. Sources of shared variability among body shape characters at marketing age in new zealand white and egyptian rabbit breeds. Ann. Zootech, 49:435-45, 2000

Teguia, A.; Ngandjou, H. M.; Defang, H. \& Tchoumboue, J. Study of the live body weight and body characteristics of the African Muscovy duck (Caraina moschata). Trop. Anim. Health Prod., 40(1):5-10, 2008.

Wu, Z.; Ma, X.; Tian, S.; Li, C.; Guan, L.; Li, W. \& Wangi, H. Path analysis on weight, body dimension and ear type of Saibe rabbits. Proceedings of the $9^{\text {th }}$ World Rabbit Congress, Verona, Italy, 2008. pp.261-4.

Yakubu, A.; Salako, A. E.; Ladokun, A. O.; Adua, M. M. \& Bature, T. U. K. Effects of feed restriction on performance, carcass yield, relative organ weights and some linear body measurements of weaner rabbits. Pakistan J. Nutr., 6(4):391-6, 2007.

Yakubu, A.; Salako, A. E.; Ogah, D. M.; Barde, R. E. \& Oyefeso, S. O. Estimation of body weight from linear body measurements in domestic rabbits (Oryctolagus cuniculus). Proceedings of the $38^{\text {th }}$ Annual Conference of Agricultural Society of Nigeria, Lafia, 2004.

Correspondence to:

A. Yakubu

Department of Animal Science,

Faculty of Agriculture, Nasarawa State University,

Keffi, Shabu-Lafia Campus, NIGERIA

Email: abdul_mojeedy@yahoo.com

Received: 18-10-2008

Accepted: 08-09-2009 
